УДК 681.518 .5

\author{
${ }^{[0000-0002-7588-1055]}$ T. В. Миронюк, к.m.н., \\ e-mail: tanjamiron85@gmail.com \\ С. П. Римар, магістрант \\ e-mail: eughene87@ukr.net \\ Черкаський державний технологічний університет \\ б-р Шевченка, 460, м. Черкаси, 18006, Україна
}

\title{
АВТОМАТИЗАЦІЯ УПРАВЛІННЯ ВОДНИМИ МІКРОЕКОСИСТЕМАМИ
}

Робота покликана стимулювати інтерес до галузі автоматизаиії господарств тваринництва, підвищення якості управління водними екосистемами иляхом автоматизації процесів, які відбуваються в середовищі їх існування, зокрема у водному середовищі життєдіяльності екзотичних риб - акваріумі. Дослідження наявних розробок $і$ готових систем показало, що в своїи основі існуючі пристрої являють собою громіздкі системи, які вузько спеціалізовано пристосовані під кожну водну мікросистему. Виходячи з результатів дослідження, було вирішено створити уніфікований пристрій із простим інтерфейсом, який би підходив для усіх звичайних видів акваріумів, без спеціального попереднього налаштування системи під окремо взяте штучне водне середовище.

Ключові слова: мікроконтролерні системи, водні екосистеми, автоматизачія прочесів, вимірювання, Arduіпо.

Вступ. При управлінні тими чи іншими процесами у різних галузях господарства i при виконанні великого обсягу повторюваних дій раз за разом ефективність роботи людини зменшується, з'являються втома, затримка реакції тощо. Під дією різних зовнішніх чинників може зростати схильність людини до прийняття хибних (помилкових) рішень, що тісно пов'язане 3 таким явищем, як людський фактор [1]. Тому розвиток високих технологій, робототехніки і автоматизації у різних сферах діяльності людини спрямований в тому числі й на те, щоб зменшити обсяги важкої монотонної роботи та уникнути низки спричинених нею помилок, що, в свою чергу, знизить вплив людського фактора на автоматизовані системи.

В сфері управління мікроекосистемами на господарських підприємствах (лісові та тваринні господарства, ферми тощо) чи у побуті (при догляді за домашніми улюбленцями) вплив людського фактора також має місце та являється суттєвим. Адже тут людина несе відповідальність за живі організми. I рівень відповідальності не залежить від того, чи то $\epsilon$ тварини, яких людина вирощує, щоб у перспективі перетворити на їжу (як це відбувається на фермах), чи то є домашні тваринки, яких людина тримає виключно для задоволення своїх естетичних потреб (як це відбувається у випадку, наприклад, з домашнім акваріумом).

(C) Т. В. Миронюк, С. П. Римар, 2020 DOI: $10.24025 / 2306-4412.2 .2020 .197278$
Об'єктом даного дослідження став такий вид діяльності, як акваріумістика, що пов'язаний із моделюванням екосистеми у замкнутому штучному водоймищі [2]. Більшість мешканців водного середовища $€$ досить вибагливими до складових гідросфери, в якій існують. Навіть невелика зміна стану окремої компоненти водної системи може призвести до незворотних змін у штучній гідросфері. Тому уважне спостереження за водоймищем і вчасна реакція на зміну різних чинників, являється важливою проблемою в сфері, що досліджується. Нині при швидкому розвитку технологій автоматизації залучення інноваційних мікропроцесорних систем знаходить широке застосування в таких сферах діяльності, як управління водними мікроекосистемами [3].

Мікропроцесорні і мікроконтролерні системи набули значного поширення в промисловості. Саме там такі системи починають застосовувати швидкими темпами, удосконалюючи методи догляду за тваринами. На великих підприємствах-фермах, де кількісна характеристика тварин досягає максимуму, автоматизація процесів потрібна в обов'язковому порядку, адже вона зводить до мінімуму людський фактор [4].

У межах акваріумістики такі системи $€$ досить специфічними і мають невелику поширеність у зв'язку зі складністю налашту- 
вання під окремо взятий акваріум і необізнаністю 3 корисним ефектом від імплементації таких автоматичних систем. Тому робота по розробці автоматизованої системи управління водними мікроекосистемами була спрямована на дослідження наявних зразків систем автоматизації підтримки гідросфери акваріума. Було проведено порівняння існуючих зразків та спроектовано уніфіковану мікроконтролерну систему для широкого спектра штучних гідросфер.

Метою дослідження $\epsilon$ підвищення ефективності управління мікроекосистемою побутових акваріумів на основі мікроконтролерної системи. ції:

Ця система має виконувати такі функ-

- фіксація стану компонентів середовища життєдіяльності живих організмів;

- запуск відповідних окремих пристроїв системи у відповідь на реакцію датчиків, що вимірюють параметри водної мікроекосистеми (водоймища, акваріума тощо).

Для реалізації поставленої мети сформовано та вирішено наступні завдання:

- провести дослідження актуальності проектування та розробки пристрою, шляхом визначення переваг та недоліків готових рішень;

- розглянути методи проектування та розробки автоматизованих систем на основі мікроконтролерів;

- використовуючи результати досліджень та експериментів, спроектувати і розробити ефективну автономну мікроконтролерну систему для управління штучним середовищем життєдіяльності тварин

Опис об'єкта та методу дослідження. Об'єктом дослідження цієї роботи є процес управління водною мікроекосистемою на прикладі побутових акваріумів.

Для підтримання правильного режиму існування тварин у закритих штучних середовищах необхідно уважно спостерігати за різними компонентами штучного середовища i вчасно реагувати на найменші зміни їх показників. При автоматизації таких дій обов'язковою $є$ вимога досконального відпрацювання усіх частин системи і вчасного інформування користувача про несправності окремих модулів.

Виходячи $з$ цього в підходах до проектування та розробки автоматизованих систем необхідно чітко дотримуватись потрібних ме-

(C) Т. В. Миронюк, Є. П. Римар, 2020 DOI: $10.24025 / 2306-4412.2 .2020 .197278$ тодів і практик, прийнятих до проектування і конструювання подібних пристроїв. Результатом синтезу автономних мікроконтролерних систем управління при дотриманні таких методик є надійні і відмовостійкі пристрої, які можуть служити довго.

Досліджуючи наявні зразки систем автоматизованого керування середовищем існування водних мешканців, можна зробити висновки, що всі наявні моделі спроектовані 3 урахуванням особливих специфікацій того чи іншого типу акваріума, а тому серійний випуск таких пристроїв $є$ дещо складним. Наприклад, система AquaDigitalLife виробництва компанії АкваКоралл являється потужною системою 3 великою кількістю налаштувань, пристроїв спостерігання за водними мешканцями і системами аварійного перемикання дублюючих пристроїв [5]. Однак така громіздка система створюється на замовлення зоопарків і океанаріумів, де кількість мешканців великих за площею акваріумів може досягати тисяч організмів. Користувачі звичайних домашніх акваріумів зазвичай змушені використовувати кустарно виготовлені, також на замовлення, або сконструйовані вручну автоматизовані системи, що заточені під окремо взяту гідросферу акваріума. Звичайні користувачі таких систем будуть стикатися з проблемами спеціального налаштування і підтримки. Тому проектування уніфікованого, простого, але в той же час ефективного пристрою $є$ актуальною проблемою.

Одним із основних підходів до проектування таких автономних систем $\epsilon$ повне задоволення складеного технічного завдання 3 можливістю покрокового додавання і тестування потрібного функціоналу, за допомогою програмування та приєднання додаткових модулі та датчиків до головного мікроконтролеpa [6].

Розробка високотехнологічного пристрою, так само, як і розробка програмного забезпечення та й, взагалі, будь-якого автоматизованого винаходу за загальноприйнятою практикою проходить через декілька важливих етапів:

1. Ідея являється етапом визначення необхідного функціоналу пристрою.

2. Умови реалізації, що включає в себе етап підрахунку необхідної кількості часу та ресурсів, які розробник може витратити на конструювання пристрою. 
3. Вибір інструментів і компонентів, що являє собою вибір потрібних компонентів та інструментів для реалізації ідеї створення пристрою з урахуванням умов для реалізації.

4. Моделювання. Етап, що представляє собою створення віртуальної моделі у відповідному програмному забезпеченні.

5. Програмування. Етап власне створення скетчу роботи мікроконтролера і його тестування.

6. Складання, тобто процес під'єднання всіх компонентів, фіксування їх у корпусі (для платформ проектування типу Arduino), або створення за схемою друкованої плати і прошивка мікроконтролера.

Перед проектуванням пристрою було проведене дослідження роботи існуючих мікропроцесорних систем для обрання основи платформи для реалізації. На сьогоднішній день $\epsilon$ вибір із трьох популярних мініатюрних мікропроцесорних систем: Arduino, Rasperry Pi та BeagleBoard. Останні дві $є$ скоріше мікрокомп'ютерами, тому що мають потужніші процесори і більший об'єм оперативної пам'яті, ніж Arduino. Також ці дві системи мають майже всі основні інтерфейси, що має звичайний комп'ютер, і можуть завантажуватись і працювати під керуванням операційних систем Linux, Android чи Windows CE. Для побудови простого уніфікованого пристрою, що буде реалізовано в досліджуваній роботі, найкращим вибором буде апаратно-програмна платформа Arduino.

Основними аргументами для вибору цієї платформи як основи для майбутньої автоматизованої системи $\epsilon$ те, що Arduino спроектовано спеціально як просту і мініатюрну платформу для прототипування пристроїв робототехніки чи пристроїв типу «розумний дім». Виходячи 3 цього, сама плата не має зайвих і не потрібних для таких задач інтерфейсів та модулів, що, в свою чергу, зменшує іiі ціну та розміри. В серії Arduino існує, як мінімум, 15 видів мікроконтролерів, які відрізняються розмірами, наявністю тих чи інших інтерфейсів тощо [6].

В ході ознайомлення 3 кожним типом існуючих моделей платформи Arduino було обрано одну з них, яка $є$ найпопулярнішою на сьогодні та забезпечена необхідним для розробки інтерфейсом і потужністю. Такою платформою $€$ Arduino UNO.

Вигляд цієї платформи зображено на рисунку 1 [6].

(C) Т. В. Миронюк, С. П. Римар, 2020

DOI: $10.24025 / 2306-4412.2 .2020 .197278$
Основними датчиками системи $є$ прості модульні пристрої, спеціально спроектовані та розроблені для використання їх при розробці автоматизованих систем керування на базі мікроконтролера ATmega328P у складі мікроконтролерної системи Arduino.

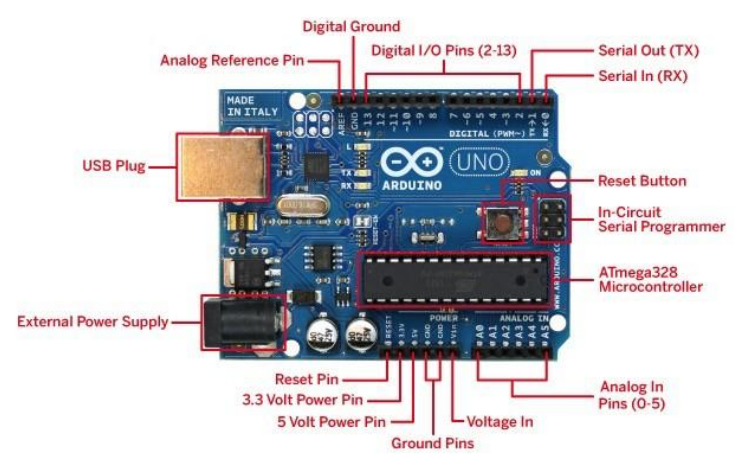

Рисунок 1 - Платформа Arduino UNO

При дослідженні функціональних вимог до майбутньої системи управління було вирішено, що система повинна задовольняти низку вимог, таких як: вимірювання температури води, вимірювання рівня води та вимірювання інтенсивності світла в акваріумі. У відповідь на отримані й оброблені дані від датчиків система має вмикати відповідні пристрої (подавати напругу через замикання кола цих пристроїв, подаючи керуючий сигнал на реле), а саме, обігрівач, аератор, світлодіодні лампи. Ще однією задачею системи є можливість керуватися віддалено за допомогою пульта. Для вирішення цих задач було використано перелік відповідних датчиків, які зображено на рисунку 2 [7].

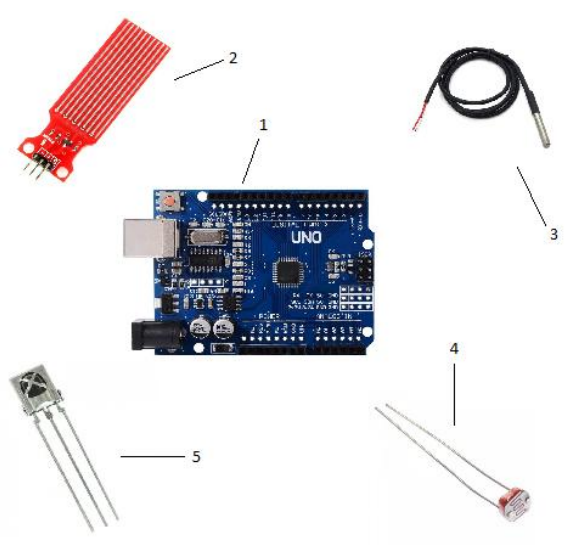

Рисунок 2 - Платформа Arduino UNO [7]

Датчик температури. Датчиком такого типу $\epsilon$ звичайний терморезистор, простий 
пристрій, опір якого змінюється зі зміною його температури. Ці датчики поширені всюди, від систем протипожежної безпеки до систем вимірювання метереологічних станцій разом 3 датчиками вологості та тиску. В системі, що проектується, для підтримання водної екосистеми використовується датчик з маркуванням DS18B20 у вологозахищеному корпусі, що дає йому змогу працювати навіть у рідині [7].

Датчик освітлення. Побудований на основі такого поширеного в електроніці елемента, як фоторезистор. Як і звичайний резистор, фоторезистор основною своєю характеристикою має опір провідника. Однак фоторезистор динамічно змінює свій питомий опір залежно від освітлення [8]. У пристрої, що проектується, датчик освітлення на базі фоторезистора буде подавати сигнал у випадку, коли світло лампи буде тускніти до певного рівня, що не буде прийнятним для мешканців водоймища.

ІЧ-приймач. Являє собою фотодіод, в якому під дією інфрачервоного випромінювання, що надходить від пульту керування, починає йти струм. Цей струм у вигляді сигналу надходить в основну плату, де й обробляється закладеною в мікроконтролер програмою.

Датчик рівня води. Цей датчик складається 3 витравлених на підкладці провідників,

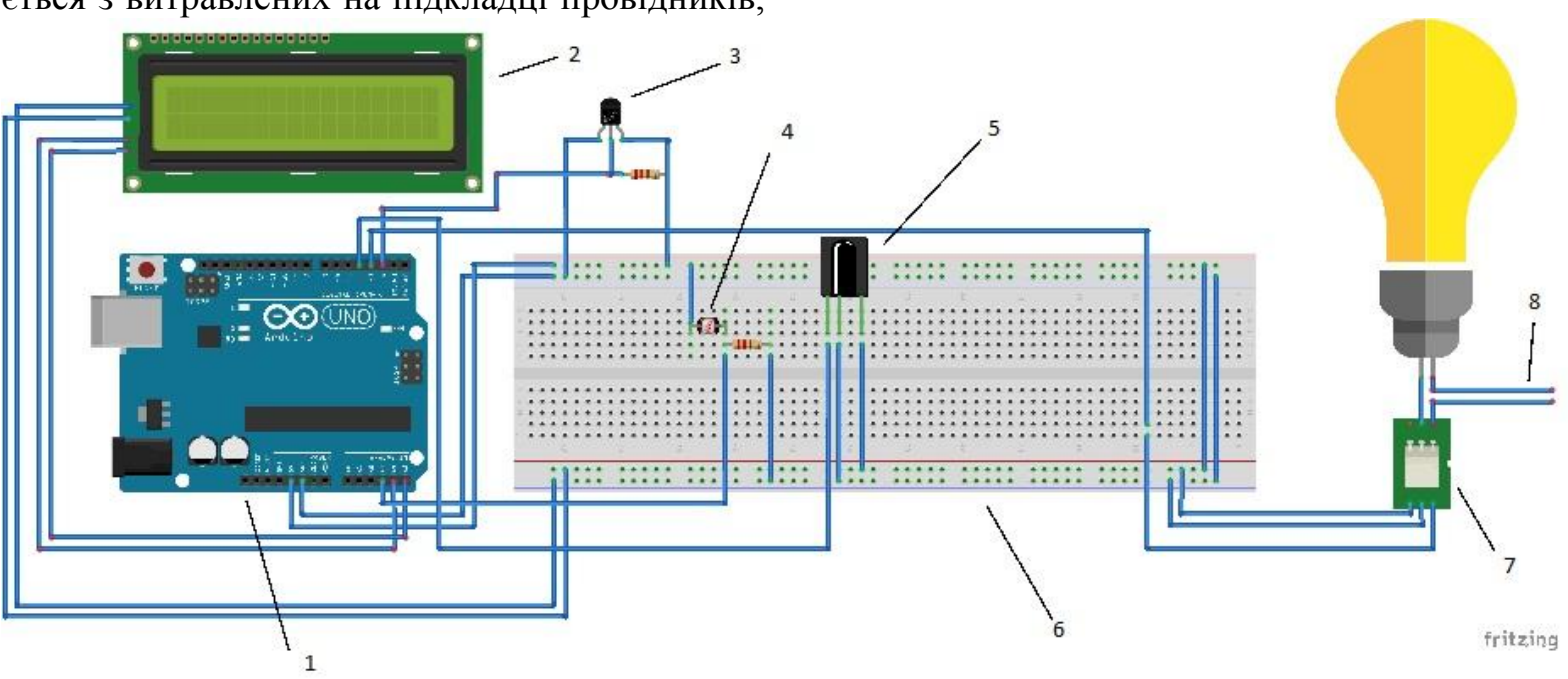

Рисунок 3 - Спрощена схема пристрою автоматизації керування акваріумом

1 - Платформа Arduino UNO, 2 - рідкокристалічний дисплей, 3 - датчик температури (терморезистор), 4 - датчик освітленості (фоторезистор), 5 - ІЧ-приймач, 6 - плата макетування (бредборд), 7 - електромеханічне реле, 8 - контакти живлення лампи

Алгоритм роботи системи. У рамках цієї роботи проводилося дослідження стану штучного водоймища в процесі керування які при зануренні в рідину замикаються і відповідно до рівня занурення видають відповідний сигнал. У пристрої, що проектується, цей датчик надсилає сигнал на головну плату при виникненні протікань в акваріумі чи випаровувань недопустимого рівня води. Сигнал передається на плату Arduino i обробляється згідно з завантаженою прошивкою.

Окремі підсистеми сконструйованого пристрою можна налаштовувати під потрібні значення за допомогою пульта віддаленого керування. Налаштовуватися можуть такі значення системи:

- ввімкнення/вимкнення світла у визначений час доби;

- ввімкнення/вимкнення аератора у визначений час доби;

граничний рівень температури води, при якому потрібно вмикати обігрівач;

- подача корму у визначений час доби.

Задля зручності налаштування цих підсистем у системі передбачений модуль рідкокристалічного дисплею I2C 1602, на якому буде відображатися запрограмоване меню налаштувань пристрою.

Вигляд пристрою, що проектується та буде реалізовано, наведено на рисунку 3. ним розробленою мікропроцесорною системою і порівняння його 3 попереднім станом, 
де більший вплив на середовище мав людський фактор.

Після першого ввімкнення спроектованої системи на екрані з'явиться напис привітання, після якого одразу з'явиться меню налаштування підсистем. За допомогою цього меню користувач зможе налаштувати необхідні параметри для керування своїм акваріумом, якщо вказані за замовчуванням значення, закладені одразу в прошивці, його не влаштовують. Одразу після подачі живлення на пристрій він починає працювати за складеним алгоритмом і вказаними налаштуваннями. Окремі датчики підсистем починають періодично (кожні 15 секунд) вимірювати температуру, освітленість, рівень води, а також час, і посилати отримані дані на головний мікроконтролер ATmega328P, який за складеним скетчем вирішує, яку підсистему слід увімкнути або який сигнал подати користувачу.

Основним методом визначення працездатності спроектованого пристрою і його правильного функціонування було спостерігання і фіксація стану водного середовища акваріума до застосування спроектованого приладу (тобто, виконуючи процеси догляду за штучним водоймищем в ручному режимі) та після його введення в експлуатацію. Вимірювалися і досліджувалися такі компоненти:

- температура води;

- жорсткість та хімічний склад води;

- інтенсивність світла протягом доби;

- загальний стан водного середовища, визначений наочно.

Проведений дослід 3 порівняння стану водної мікроекосистеми на прикладі акваріума включав вимірювання жорсткості води, рівня температури у рівні проміжки часу, складу води та зовнішні спостереження за виглядом водоймища у процесі ручного управління та при управлінні розробленою мікроконтролерною системою [9].

Загалом у ході проведення експерименту було виявлено, що температура води завдяки датчикам і алгоритму роботи пристрою завжди залишалася на прийнятному для живих організмів акваріума рівні, на противагу тому, що було до використання розробленої автоматизованої системи (через вплив людського фактора обігрівач інколи не встигали вмикати, тому що не звертали увагу на температуру води в резервуарі). Таким чином, світло не завжди вмикалося в потрібний час, а при тривалій відсутності людини біля акварі- ума i, відповідно, без іï контролю відчувалася нестача освітлення для риб і рослин.

Вищезазначені чинники та деякі інші, наприклад недостатня аерація води, призводили нехай не до критичної, але до суттєвої зміни рівня $\mathrm{pH}$, що негативно впливало на живі організми акваріума. Вплив кислот і лугів на акваріумну воду є одним із найважливіших компонентів, за якими потрібно уважно стежити і оперативно реагувати на їх навіть найменшу зміну [10]. При зменшенні або збільшенні рівня $\mathrm{pH}$ у мешканців водоймища можуть розвиватися хвороби, вони можуть втратити змогу до репродукції, i загальний стан риб буде незадовільним. При проведенні експерименту з порівняння стану води використовувалися спеціальні пристрої для тестування води на рівень $\mathrm{pH}$.

Також однією $з$ переваг при використанні автоматизованої системи є зміна зовнішнього вигляду штучного водного середовища.

Як результат було виявлено, що автоматизована система в змозі звести до мінімуму людський фактор помилок у процесі керування важливими компонентами штучного водного середовища існування живих організмів, i тим самим покращити загальний стан акваріума автономно, без участі в цьому процесі людини.

Висновки. В зв'язку з тим, що розробка автоматизованих систем керування штучними середовищами існування живих організмів $\epsilon$ досить вузькою темою в дослідженнях, тому готових рішень і серійного виробництва таких пристроїв не спостерігається, навіть незважаючи на швидке поширення новітніх технологій і розробок у сфері робототехніки. Тож це дослідження також покликане підвищити інтерес суспільства та науки до досліджень у цій галузі технологій автоматизації.

Наукова новизна отриманих результатів полягає в підвищення ефективності управління мікроекосистемою побутових акваріумів на основі мікроконтролерної системи.

Практичне значення досліджуваної роботи полягає в розробці експериментального прототипу пристрою для підвищення якості управління водними екосистемами за сформованим алгоритмом проектування.

Отже, синтезована за допомогою розглянутих методів мікроконтролерна система дає можливість автономно, без затрат часу i мінімізуючи людський фактор, виконувати поставлені задачі, а саме: 
- вимірювати температуру водного середовища і вмикати/вимикати обігрівач, коли це потрібно;

- вимірювати рівень води в акваріумі i, коли він опуститься нижче визначеного рівня (вода випаровується з часом, і їі рівень в акваріумі падає), подавати відповідний сигнал;

- вимірювати кількість світла, яке дає лампа i, в разі зниження потужності лампи, подавати відповідний сигнал про недостатній рівень світла;

- керувати віддалено за допомогою пульта керування, посилаючи команди на модуль ІЧ-порту.

У процесі вирішення поставлених у роботі завдань було одержано такі результати:

- проведено дослідження наявних рішень автоматизованих систем та обгрунтовано актуальність теми;

- розглянуто і досліджено методи синтезу автоматизованих систем;

- на основі проведених експериментів та досліджень створено мікроконтролерну систему управління водним середовищем існування мікроекосистем.

Отже, аналізуючи отримані в результаті дослідження результати на прикладі акваріуму, було доведено доцільність подальшого розвитку і популяризації розробленого способу та алгоритму проектування для впровадження у автоматичних засобах керування.

\section{Список використаних джерел}

[1] Н. В. Загуменна, "Людський фактор та специфіка його активізації у соціальнофілософських дослідженнях", Альманах. Філософські проблеми гуманітарних наyк, № 16, с. 68-72, 2010.

[2] М. Бейли, и П. Бергресс, Золотая книга аквариумиста. Аквариум ЛТД, 2004.

[3] О. В. Барало, П. Г. Самойленко, С. С. Гранат, та В. О. Ковальов, Автоматизація технологічних прочесів і системи автоматичного керування. Київ: Аграрна освіта, 2010.

[4] А. В. Нєлєпова, Р. О. Трибрат, та Л. В. Бондаренко, Програмне управління проиесами у галузі. Київ: Кафедра, 2018.

[5] aquacoral.livejournal.com - Блог компаніï AquaCoral. [Електронний ресурс]. Режим доступу: https://aquacoral.livejournal.com.
[6] B. Massimo, Getting Started with Arduino, 2nd Edition. MakerMedia, 2011.

[7] DS18B20 DATASHEET. [Електронний ресурс]. Режим доступу: https://datasheets.maximintegrated.com/en/d s/2812.pdf.

[8] Э. О. Богданов, Фоторезисторы $u \quad u x$ применение. Энергия, 1978.

[9] В. І. Мальцев, . О. Карпова, та Л. М. Зуб, Визначення якості води методами біоіндикаціï: наук.-метод. посіб. Київ: IHEKО, 2011.

[10] Р. Бейтс, Определение рH. Теория $u$ практика. Изд. 2-е, испр. Ленинград: Химия, 1972.

\section{References}

[1] N. V. Zagumennaya, "Human factor and specifics of its activation in socialphilosophical researches", Almanakh. Filosofski problemy humanitarnykh nauk, no. 16, pp. 68-72, 2010 [in Ukrainian].

[2] M. Bailey, and P. Bergress, The aquarist's golden book. Aquarium LTD, 2004 [in Russian].

[3] O. V. Baralo, P. G. Samoilenko, S. E. Hranat, and V. O. Kovalyov, Automation of technological processes and automatic control system. Kyiv: Ahrarna osvita, 2010 [in Ukrainian].

[4] A. V. Nelepova, R. O. Tribrat, and L. V. Bondarenko, Software process management in the industry. Kyiv: Kafedra, 2018 [in Ukrainian].

[5] aquacoral.livejournal.com - Blog of AquaCoral company. [Online]. Available: https://aquacoral.livejournal.com.

[6] B. Massimo, Getting Started with Arduino, 2nd Edition. MakerMedia, 2011.

[7] DS18B20 DATASHEET. [Online]. Available: https://datasheets.maximintegrated.com/ en/ds/2812.pdf.

[8] E. O. Bogdanov, Photoresistors and their using. Energy, 1978 [in Russian].

[9] V. I. Maltsev, G. O. Karpova, and L. M. Zub, Determination of water quality by bioindication methods: sci.-method. manual. Kyiv: INEKO, 2011 [in Ukrainian].

[10] R. G. Bates, Determination of $p H$. Theory and practice. 2nd Edition, John Wiley \& Sons, New York, London, Sydney, Toronto, 1973. 
T. V. Myroniuk, $P h . D$., e-mail: tanjamiron85@gmail.com

E. P. Rymar, graduate student e-mail: eughene87@ukr.net Cherkasy State Technological University Shevchenko blvd, 460, Cherkasy, 18006, Ukraine

\section{AUTOMATION OF MANAGEMENT OF WATER MICRO ECOSYSTEMS}

The work is intended to stimulate the interest in the field of automation of livestock farms, improve the quality of management of aquatic ecosystems by automating the processes that occur in their habitat, in particular in the aquatic environment of exotic fish-aquariums. Before creating such an automated system, a number of ready-made solutions have been investigated, as well as methods for their design and synthesis have been studied. The research of existing developments and finished systems has shown that at the heart of such devices there are bulky systems sharpened under each individual aquarium. Based on the results of the study, it is decided to create a unified device, with a simple interface that would be suitable for all ordinary types of aquariums, without special preadjusting of the system under a separate artificial aquatic environment. Comparing the available and popular tools for rapid prototyping of microcontrollers, it is decided to focus on the Arduino platform. The great attention and interest in the platform of radio amateurs and professionals, and, based on the previous statement, the high prevalence of prefabricated modules and components for the platform have helped to make the right choice of the basis of an automated system for managing artificial aquatic ecosystems habitat. In the process of reviewing ready-made solutions in the market, systematization of the received data and studying the relevant specialized literature, the algorithm of work of the future device has been drawn up, the necessary elements for the system construction have been selected, the schematic diagram of the device has been modeled and the device has been assembled and tested on available aquarium. Testing of the synthesized system on a real reservoir with organisms proves the urgency of creating such an autonomous control device, because the state of the environment has been maintained exactly as programmed by the system. Responding to changing the state of the components of the aquatic environment with a number of sensors, the system manages the system devices themselves, thereby maintaining the desired balance of the aquarium with minimizing the human factor. duino.

Keywords: microcontroller systems, aquatic ecosystems, process automation, measurement, Ar-

Стаття надійшла 13.11.2019

Прийнято 28.12.2019

(C) Т. В. Миронюк, Є. П. Римар, 2020

DOI: $10.24025 / 2306-4412.2 .2020 .197278$ 